\title{
Pengenalan Wajah Menggunakan Implementasi T-shape Mask pada Two Dimentional Linear Discriminant Analysis dan Support Vector Machine
}

\author{
Ahmad Reza Musthafa ${ }^{1}$, Alif Akbar Fitrawan ${ }^{2}$ Supria $^{3}$ \\ Program Studi Pasca Sarjana, Fakultas Teknik Informatika, Institut Teknologi Sepuluh November \\ Jl. Raya ITS, Kampus ITS, Sukolilo, Surabaya 60111 \\ E-mail: ${ }^{1}$ reza14@mhs.if.its.ac.id, ${ }^{2}$ alif14@mhs.if.its.ac.id, ${ }^{3}$ supria14@mhs.if.its.ac.id
}

Masuk: 3 Juni 2015; Direvisi: 21 Juli Juli 2015; Diterima: 23 Juli 2015

\begin{abstract}
Face recognition is the identification process to recognize a person's face. Many studies have been developing face recognition methods, one of which is the Two Dimensional Linear Discriminant Analysis (TDLDA) which has pretty good accuracy results with the method of classification Support Vector Machine (SVM). With more training data can add computational time. TDLDA using all the piksel image as input to be processed for feature extraction. Though not all the objects in the area of the face is a significant feature in face recognition. In this study, the proposed use of the T-shape with only use a significant part is the eyes, nose, and mouth are integrated with TDLDA and SVM. The result could reduce computing time on face recognition $21.56 \%$ faster than TDLDA method. The accuracy of the results in this study was $91 \%-96 \%$ which is close to the level of accuracy without using a mask on the face.
\end{abstract}

Keyword: face recognition, T-shape, TDLDA, Support vector machine.

\begin{abstract}
Abstrak. Pengenalan wajah merupakan proses identifikasi untuk mengenali wajah seseorang. Telah Banyak penelitian yang mengembangkan metode pengenalan wajah, salah satunya adalah Two Dimensional Linear Discriminant Analysis (TDLDA) yang memiliki hasil akurasi yang cukup baik dengan metode klasifikasi Support Vector Machine (SVM). Dengan semakin banyak data training dapat menambah waktu komputasinya. TDLDA menggunakan semua piksel citra sebagai masukan yang akan diproses untuk ekstrasi fitur. Padahal tidak semua objek pada area wajah merupakan fitur yang signifikan dalam pengenalan wajah. Dalam penelitian ini diusulkan penggunaan $T$ shape dengan hanya menyimpan bagian yang signifikan yaitu mata, hidung, dan mulut yang diintegrasikan dengan TDLDA dan SVM. Hasilnya dapat mengurangi waktu komputasi pada pengenalan wajah 21,56\% lebih cepat daripada metode TDLDA. Hasil akurasi pada penelitian ini adalah 91\%-96\% yang mendekati tingkat akurasi tanpa menggunakan mask pada wajah.
\end{abstract}

Kata Kunci: pengenalan wajah, T-shape, TDLDA, Support vector machine.

\section{Pendahuluan}

Selama hidupnya manusia memiliki kemampuan mengenal wajah puluhan bahkan ratusan. Sekalipun jarang bertemu, seseorang dapat mengenali wajah walaupun telah mengalami perubahan wajah pada orang yang dikenalinya. Dari hal inilah banyak dikembangkan teknik biometrik yang mampu mendeteksi dan mengidentifikasi wajah dengan memanfaatkan masukan berupa citra wajah. Saat ini, pengenalan wajah melalui aplikasi komputer dibutuhkan untuk mengatasi berbagai masalah, antara lain dalam identifikasi pelaku kejahatan, pengembangan sistem keamanan, pemrosesan citra maupun film, dan interaksi manusia komputer.

Para pakar pattern recognition telah banyak melakukan penelitian terhadap teknik pengenalan wajah ini, mengajukan teknik baru yang lebih baik dari teknik yang lama. Akan tetapi teknik-teknik baru yang diajukan tersebut masih belum bisa mendapatkan hasil akurasi yang optimal. Dua hal yang menjadi masalah utama pada identifikasi wajah adalah proses ekstraksi fitur dari sampel wajah yang ada dan juga teknik klasifikasi yang digunakan untuk mengklasifikasikan wajah yang ingin dikenali berdasarkan fitur-fitur yang telah dipilih 
(Damayanti, 2010). Ekstraksi fitur adalah proses untuk mendapatkan ciri-ciri pembeda yang membedakan suatu sampel wajah dari sampel wajah yang lain, bagi sebagian besar aplikasi pattern recognition, teknik ekstraksi fitur yang handal merupakan kunci utama dalam penyelesaian masalah pattern recognition.

Metode Two Dimensional Linear Discriminant Analysis (TDLDA) adalah salah satu teknik ekstraksi fitur. Metode ini menilai secara langsung matrik within-class scatter dari matrik citra tanpa transformasi citra ke vektor, dan hal itu mengatasi singular problem dalam matrik within-class scatter (Gao, 2008). TDLDA menggunakan fisher criterion untuk menemukan proyeksi diskriminatif yang optimal (Kong, 2005). Metode TDLDA dengan klasifikasi Support Vector Machine (SVM) memiliki hasil yang optimal dibandingkan TDLDA KNN, 2DPCA, dan Fisherface (Damayanti, 2010).

Setiap piksel pada citra wajah adalah sebuah fitur tersendiri, semakin besar dimensi citra maka fitur yang akan diproses untuk pengenalan wajah semakin banyak dan waktu komputasinya semakin tinggi. Semakin banyak jumlah data training juga akan semakin menambah waktu komputasinya (Zheng, 2008). Metode TDLDA menggunakan semua area citra wajah sebagai data inputan, padahal tidak semua area wajah merupakan bagian yang signifikan dalam pengenalan wajah (Koc, 2014).

Pada penelitian ini diusulkan metode pengenalan wajah dengan mengintegrasikan $T$ shape terhadap TDLDA dan support vector machine sebagai klasifikasi pengenalan wajah, sehingga diharapkan dengan integrasi T-shape Mask pada TDLDA tersebut mampu mengurangi waktu komputasi pada proses pengenalan wajah, dengan hasil akurasi pengenalan wajah yang hampir mendekati metode ekstrasi fitur TDLDA. Penggunaan masker T-shape pada wajah digunakan untuk menentukan Region of Interest (ROI) pada wajah. Fitur pada area wajah seperti mata, alis, hidung dan bibir adalah bagian yang paling signifikan pada wajah perlu disimpan dan menghilangkan piksel yang tidak signifikan seperti di bagian dahi, dagu, dan pipi.

\section{Pendekatan dan Tinjauan Pustaka}

\subsection{Pengenalan Wajah}

Pengenalan wajah merupakan sebuah cara bagaimana mengenal wajah seseorang. Pengenalan wajah manusia tidak hanya dapat dilakukan oleh manusia saja, namun sekarang ini pengenalan wajah dapat dilakukan oleh aplikasi komputer. Telah banyak orang yang menggunakan aplikasi pengenalan wajah, yang digunakan sebagai keamanan, pengawasan dan interaksi cerdas antara manusia dan komputer (Gao, 2008). Fitur-fitur pada area wajah pada setiap orang memiliki perbedaan, sehingga dengan fitur-fitur itulah komputer dapat membedakan wajah antara manusia satu dengan yang lainnya.

\subsection{Haar-Like Feature}

Haar-like features merupakan rectangular (persegi) features, yang memberikan indikasi secara spesifik pada sebuah gambar atau image. Ide dari Haar-like features adalah untuk mengenali obyek berdasarkan nilai sederhana dari fitur tetapi bukan merupakan nilai piksel dari image obyek tersebut. Metode ini memiliki kelebihan yaitu komputasinya sangat cepat, karena hanya bergantung pada jumlah piksel dalam persegi bukan setiap nilai piksel dari sebuah citra (Chung, 2013). Pada penelitian ini Metode Haar-like features digunakan untuk mendeteksi mata dan mulut pada citra wajah seperti yang terlihat pada Gambar 1.

\subsection{T-shape Mask}

Pada wajah manusia terdapat bagian-bagian yang penting yang dijadikan acuan dalam proses pengenalan wajah yaitu mata, alis, hidung, dan mulut (Sinha, 2006). Sehingga dari bagian terpenting pada wajah tersebut dijadikan mask yang membentuk seperti huruf T sehingga dinamakan T-shape Mask yang digunakan sebagai ROI (Region of Interest) pada wajah. Bagian wajah yang lain seperti rambut dan dahi dianggap sebagai bagian yang tidak terlalu penting dalam proses pengenalan wajah seseorang (Koc, 2014). Sehingga untuk mengurangi kompleksitas komputasi pada saat training mengunakan T-shape Mask dengan menghilangkan 
piksel-piksel yang dianggap tidak terlalu penting. Penggunaan T-shape Mask pada wajah dapat dilihat pada Gambar 2.

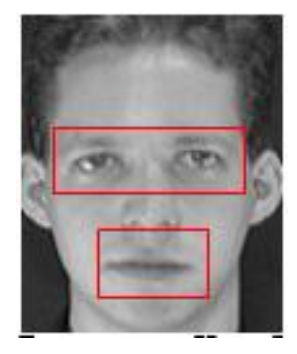

Gambar 1. Penggunaan Haar-Like Feature

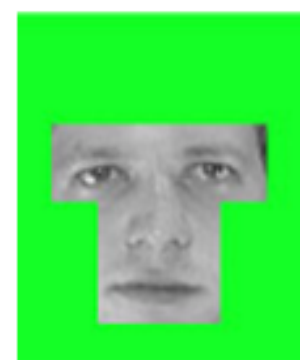

Gambar 2. Penggunaan T-shape Mask pada Wajah

\subsection{Two Dimensional Direct Linear Discriminant Analysis (TDLDA)}

Linear Discriminant Analysis telah digunakan secara luas dalam pola linier pengenalan terhadap fitur ekstraksi dan pengurangan dimensi. Hal ini dimaksudkan untuk membuat seperangkat vektor proyeksi yang sangat berbeda untuk dipadatkan sepadat mungkin pada jenis yang sama. Projection vector bekerja dalam hitungan jenis $S w$ dan antara jenis $S b$ matrix scatter. Umumnya pada aplikasi pengenalan wajah jumlah dimensi data lebih besar dibandingkan jumlah sampelnya, hal ini menyebabkan tunggalnya isi jenis scatter matrix Sw, sehingga fitur wajah tidak terekstraksi dengan baik. Dalam penelitian ini digunakan metode Two Dimensional Linier Discrimination Analysis (TDLDA) untuk ekstraksi fitur, yang menilai secara langsung isi jenis scatter matrix tanpa pencitraan terhadap transformasi vektor, sehingga mengurangi masalah tunggal dalam isi jenis scatter matrix $(\mathrm{Li}, 2005)$.

\subsection{Support Vector Machine}

Pengklasifikasian wajah manusia menggunakan konsep Support Vector Machine (SVM) yang memiliki hasil pengenalan wajah yang cukup baik dengan tingkat kebenaran yang lebih baik (Damayanti, 2010). Konsep SVM dapat dijelaskan secara sederhana sebagai usaha mencari hyperplane terbaik yang berfungsi sebagai pemisah dua buah class pada input space dapat dilihat pada Gambar 3 (Lenc, 2015).

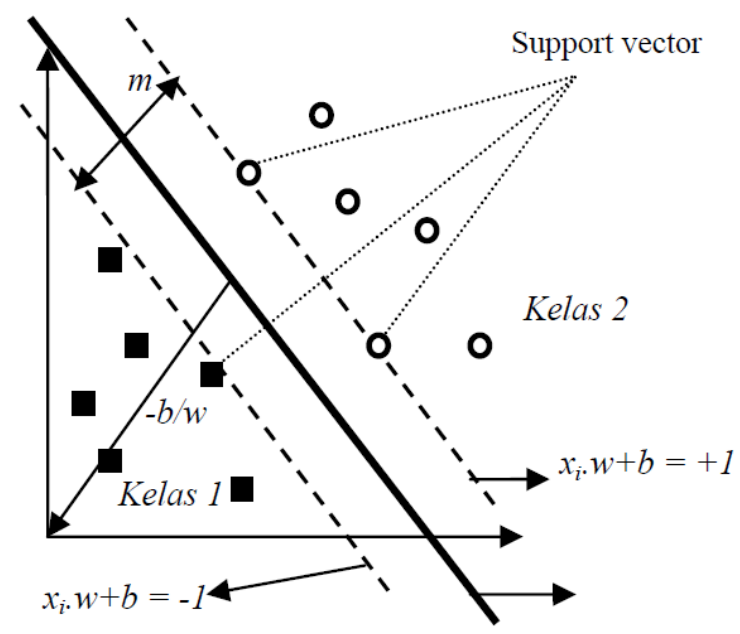

Gambar 3. Hyperline SVM

Hyperplane pemisah terbaik antara kedua class dapat ditemukan dengan mengukur margin hyperplane tersebut dan mencari titik maksimalnya. Margin adalah jarak antara hyperplane tersebut dengan pattern terdekat dari masing-masing class. Pattern yang paling dekat ini disebut sebagai support vector. SVM dapat melakukan klasifikasi data yang terpisah secara 
linier (Linearly separable) dan non-linier (nonLinear separable) (Burges, 1998). Linearly separable data merupakan data yang dapat dipisahkan secara linier.

SVM pertama kali dikembangkan oleh Vapniks untuk klasifikasi biner, namun selanjutnya dikembangkan untuk klasifikasi multiclass (banyak kelas). Pendekatannya adalah dengan membangun multiclass classifier, yaitu dengan cara menggabungkan beberapa SVM biner. Pendekatan ini terdiri dari metode satu lawan semua (One Against All) dan metode satu lawan satu (One Against One) (Hsu, 2002).

\section{Metodologi}

Proses pengenalan wajah terbagi pada tiga bagian tahapan utama seperti ditunjukkan pada Gambar 4. Pada tahap pertama dilakukan implementasi $T$-shape pada citra input, kemudian tahap kedua dilakukan ekstraksi fitur, dan tahap selanjutnya dilakukan klasifikasi dengan menggunakan SVM. Pertama kali data setelah proses TDLDA akan menghasilkan fitur yang digunakan sebagai data training. Selanjutnya setelah beberapa data dilakukan proses training sisanya digunakan sebagai data testing.

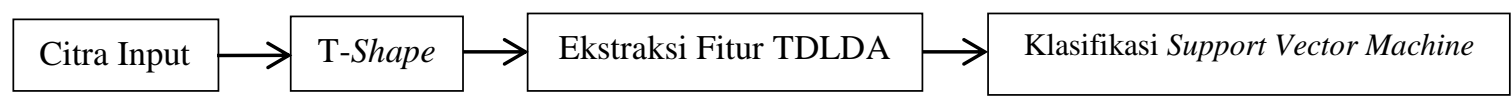

Gambar 4. Desain Penelitian Pengenalan Wajah

\subsection{T-shape}

Proses T-shape ini dilakukan untuk mengambil objek yang dianggap penting pada bagian wajah, yaitu mata, hidung, dan mulut. Bagian yang tidak penting seperti pipi, dagu, dan dahi akan dihilangkan. Proses mengambilan shape ini dengan cara interaktif ini membuat shape pada citra tanpa mendeteksi terlebih dahulu objek pada area wajah. Untuk membuat $T$-shape yang berbentuk huruf T, langkah-langkahnya sebagai berikut: (1) Membaca ukuran panjang dan lebar citra. Pada penelitian ini dataset wajah yang digunakan berasal dari ORL dengan ukuran citra 92 x 112 piksel. (2) Membuat shape horizontal warna putih dengan titik koordinat [0 20] dengan ukuran panjang dan lebar [92 62] Seperti yang ditunjukkan pada Gambar 5b. (3) Setelah terbentuk shape horizontal langkah selanjutnya membentuk shape vertical warna putih dengan titik koordinat [20 20] dengan ukuran panjang dan lebar [72 112] seperti yang ditunjukkan pada gambar 5b. (4) Kemudian scan ulang semua piksel pada citra ketika bertemu piksel berwarna putih maka simpan piksel aslinya, jika tidak maka piksel bernilai nol. Sehingga terbentuklah enhance $T$-shape yang berbentuk plus pada citra wajah seperti yang ditunjukkan gambar 5c.
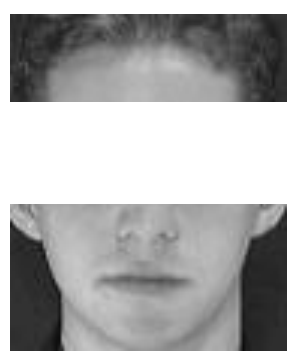

(a)
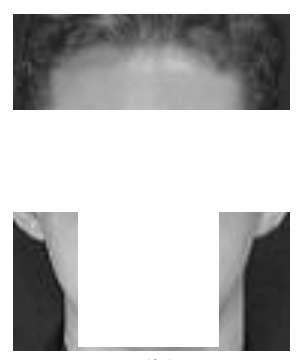

(b)

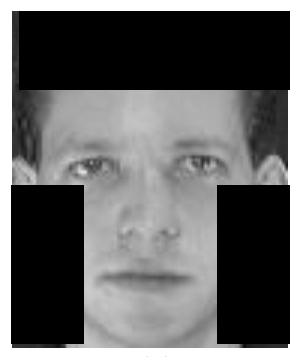

(c)

Gambar 5. Proses Enhance T-shape Secara Interaktif

\subsection{Ekstraksi Fitur}

Ekstraksi fitur pada proses pelatihan dilakukan dengan menggunakan metode TDLDA. Tahap ini bertujuan untuk mendapatkan fitur-fitur yang terpilih dari masukan data-data pelatihan. Fitur-fitur yang terpilih nantinya digunakan untuk proses klasifikasi pelatihan dan digunakan untuk ekstraksi fitur data pengujian. Citra wajah setelah dilakukan proses $T$-shape maka selanjutkan akan dijadikan sebagai basis data proses ekstraksi fitur menggunakan metode TDLDA. 
Langkah-langkah ekstraksi fitur tersebut (Damayanti, 2010) adalah sebagai berikut: (1) Basis data citra merupakan himpunan citra wajah sebanyak $n$ citra pelatihan $A_{i}=\left[A_{1}, A_{2}, \ldots, A_{n}\right]$ $(i=1,2, \ldots, n)$ dengan dimensi citra $(r \times c)$. Menghitung rata-rata citra pelatihan dari kelas ke $I$, selanjutnya menghitung rata-rata semua citra pelatihan dengan Persamaan (1) dan Persamaan (2). (2) Menetapkan matriks transformasi $R$ ukuran $\left(\mathrm{c}, \ell_{2}\right)$ yang diperoleh dari gabungan antara matriks identitas ukuran $\left(\ell_{2}, \ell_{2}\right)$ dengan matriks nol ukuran $\left(\mathrm{c}-\ell_{2}, \ell_{2}\right)$. (3) Menghitung matriks between class scatter $R$ sesuai dengan persamaan (3), selanjutnya menghitung matriks within class scatter $R$ sesuai dengan persamaan (4). (4) Hitung generalized eigenvalue $\left(\lambda_{i}\right)$ dari $S_{b}^{R}$ dan $S_{W}^{R}$ sesuai dengan persamaan (5). (5) Ambil sebanyak $\ell_{1}$ eigenvector terbesar dari langkah 5 sebagai matriks transformasi baris $(L)$, ukuran matriksnya $\left(r \times \ell_{1}\right)$. (6) Menghitung matriks between class scatter $L$ sesuai dengan persamaan (6). (7) Menghitung matriks within class scatter $L$ sesuai dengan persamaan (7). (8) Hitung generalized eigenvalue $\left(\lambda_{i}\right)$ dari $S_{b}^{L}$ dan $S_{W}^{L}$ sesuai dengan persamaan (8) menggunakan SVD. (9) Ambil sebanyak $\ell_{2}$ eigenvector terbesar dari langkah 9 sebagai matriks transformasi kolom $(R)$, ukuran matriksnya $\left(\begin{array}{ccc}c & \ell_{2}\end{array}\right)$. (10) Hitung matriks ciri ekstraksi adalah $B_{i}=L^{T} A_{i} R$, ukuran matriksnya $\left(\ell_{1} \times \ell_{2}\right)$. (11) Output: matriks ciri ektraksi $B_{i}$, matriks transformasi baris $L$, dan matriks transformasi kolom $R$.

$$
\begin{aligned}
& M_{i}=\frac{1}{n_{i}} \sum_{X \in \Pi_{i}} X \\
& M=\frac{1}{n} \sum_{i=1}^{k} \sum_{X \in \Pi_{i}} X \\
& S_{b}^{R}=\sum_{i=1}^{k} n_{i}\left(M_{i}-M\right) R R^{T}\left(M_{i}-M\right)^{T} \\
& S_{W}^{R}=\sum_{i=1}^{k} \sum_{x \in \Pi_{i}}\left(X-M_{i}\right) R R^{T}\left(X-M_{i}\right)^{T} \\
& J_{4}(L)=\operatorname{maxtrace}_{(}\left(L^{T} S_{W}^{R} L\right)^{-1}\left(L^{T} S_{b}^{R} L\right) \\
& S_{b}^{L}=\sum_{i=1}^{k} n_{i}\left(M_{i}-M\right)^{T} L L^{T}\left(M_{i}-M\right) \\
& S_{W}^{L}=\sum_{i=1}^{k} \sum_{x \in \Pi_{i}}\left(X-M_{i}\right)^{T} L L^{T}\left(X-M_{i}\right) \\
& \left.J_{5}(R)=\operatorname{maxtrace}_{(}\left(R^{T} S_{W}^{L} R\right)^{-1}\left(R^{T} S_{b}^{L} R\right)\right)
\end{aligned}
$$

\subsection{Klasifikasi}

Pengklasifikasian dengan metode SVM dibagi menjadi dua proses, yaitu proses pelatihan dan pengujian seperti yang terlihat pada Gambar 6. Pada proses pelatihan SVM menggunakan matriks ciri yang dihasilkan pada proses ekstraksi ciri pelatihan sebagai input. Sedangkan pada pengujian SVM memanfaatkan matriks ciri yang dihasilkan pada proses ekstraksi ciri pengujian sebagai input.

Algoritma pelatihan untuk masing-masing pengklasifikasi SVM biner dapat dituliskan sebagai berikut: input berupa matriks $B$ (matriks hasil ektraksi ciri pelatihan) dan vektor $Y$ sebagai pasangan input-target dan outputnya adalah $w, x, b$ (variabel-variabel persamaan hyperplane). Langkah-langkahnya (Damayanti, 2010) dijelaskan sebagai berikut: (1) Tentukan Input $(Z=B)$ dan Target $(Y)$ sebagai pasangan pelatihan dari dua kelas. (2) Hitung Kernel 
Gaussian $K\left(Z, Z_{i}\right)=\exp \left(\frac{-\left|Z-Z_{i}\right|^{2}}{\left(2 \sigma^{2}\right)}\right)$ (3) Hitung Matriks Hessian $H=K\left(Z, Z_{i} * Y * Y^{T}\right.$.

Tetapkan $c$ dan epsilon. (5) Tetapkan vektor $e$ sebagai vektor satuan yang memiliki dimensi sama dengan dimensi $Y$. (6) Hitung solusi quadratic programming: min $L(\alpha)=\frac{1}{2} \alpha^{T} H \alpha-e^{T} \alpha$, dimana $y^{T} \alpha=0$ dan $0 \leq \alpha \leq c$.

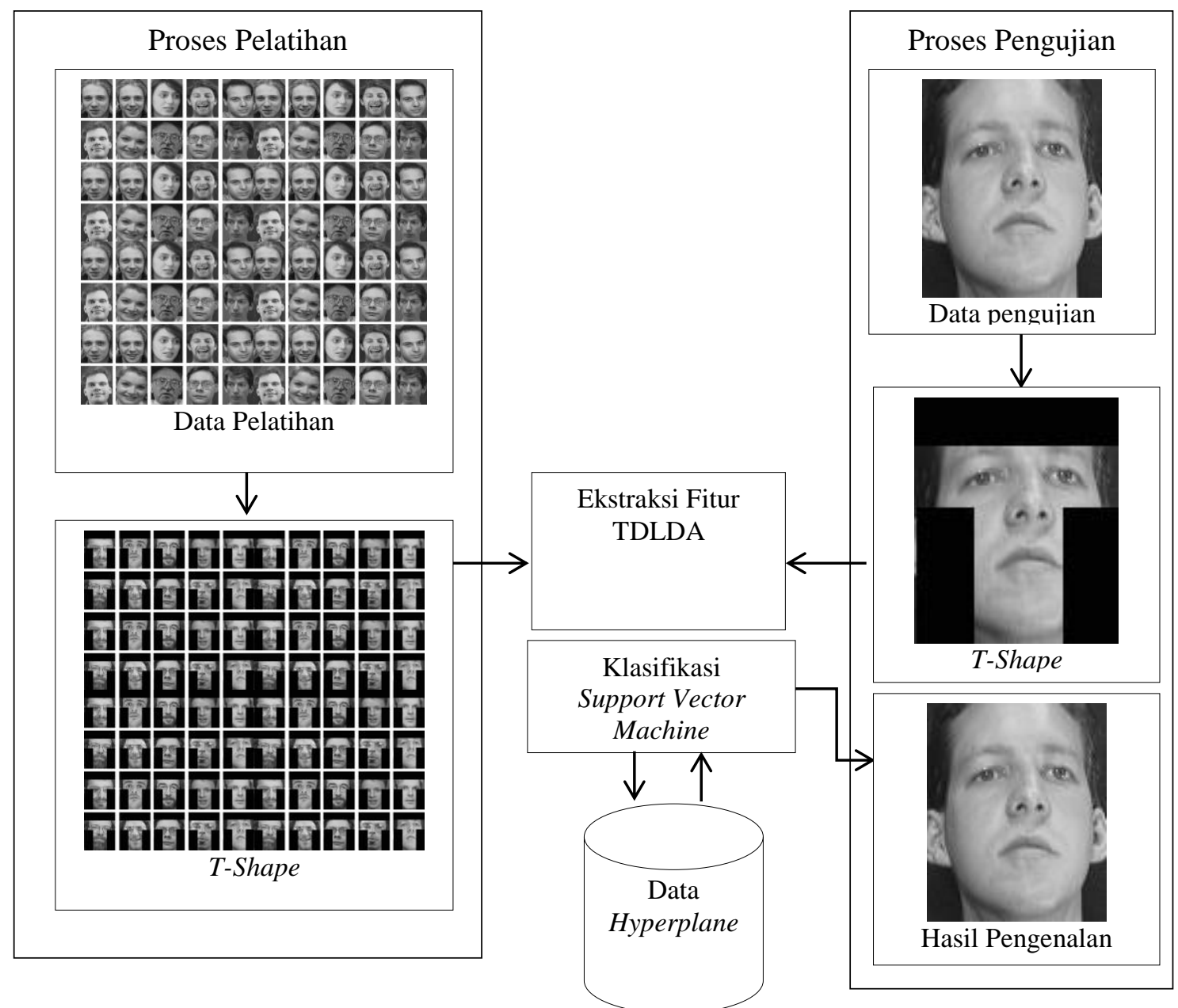

Gambar 6. Alur Klasifikasi Pengenalan Wajah

Pengklasifikasian SVM untuk multiclass One Against All akan membangun sejumlah $k$ $S V M$ biner ( $k$ adalah jumlah kelas). Data pelatihan yang sudah diproyeksikan oleh TDLDA, selanjutnya menjadi data pelatihan SVM. Jika sebaran data yang dihasilkan pada proses TDLDA mempunyai distribusi yang tidak linier, maka salah satu metode yang digunakan SVM untuk mengklasifikasikan data tersebut adalah dengan mentransformasikan data ke dalam dimensi ruang ciri (feature space). Untuk menghindari kemungkinan feature space yang tidak terhingga maka pada SVM digunakan "kernel trick". Fungsi kernel yang digunakan pada penelitian ini adalah Gaussian (Persamaan 9).

Sejumlah support vector pada setiap data pelatihan harus dicari untuk mendapatkan solusi bidang pemisah terbaik. Solusi bidang pemisah didapatkan dengan rumus $w=\Sigma \alpha_{i} y_{i} x_{i}$; $b=y_{k^{-}} w^{T} x_{k}$ untuk setiap $x_{k}$, dengan $\alpha_{k} \neq 0$. Proses pengujian atau klasifikasi dilakukan juga pada setiap SVM biner menggunakan nilai $w, b$, dan $x_{i}$ yang dihasilkan pada proses pelatihan di setiap SVM biner. Fungsi yang dihasilkan untuk proses pengujian adalah Persamaan 10, 
dimana: $i=1$ sampai $k ; x_{i}=$ support vector; $x_{d}=$ data pengujian. Output-nya adalah berupa indeks $i$ dengan $f_{i}$ terbesar yang merupakan kelas dari data pengujian.

$$
\begin{aligned}
& K(x, y)=\exp _{\left(\frac{|x-y|^{2}}{\left(2 \sigma^{2}\right)}\right)} \\
& f_{i}=K\left(x_{i}, x_{d}\right) w_{i}+b_{i}
\end{aligned}
$$

\section{Hasil dan Pembahasan}

Data yang digunakan pada eksperimen terdiri dari 400 citra wajah manusia yang berasal dari Olivetti Research Laboratorium (ORL) yang terdiri dari 40 kelas. Hasil eksperimen untuk mengetahui perbandingan hasil akurasi pengenalan wajah. Metode yang diusulkan yaitu implementasi $T$-shape interaktif pada TDLDA dibandingkan dengan model pengenalan wajah dengan TDLDA dan implementasi $T$-shape otomatis pada TDLDA. Pada proses eksperimen ini digunakan jumlah data training yang berbeda-beda yaitu pertama dilakukan dengan jumlah lima data training dengan lima data testing, kemudian enam data training dengan empat data testing dan tujuh data training dengan tiga data testing. Nilai akurasi pada pengenalan wajah ini dihitung dengan menentukan nilai dari Precission, Recall, F-Measure dan waktu komputasi pada saat proses training.

Pada model pengenalan wajah dengan TDLDA dilakukan pengenalan wajah menggunakan semua piksel-piksel pada area wajah. Jadi pada model ini citra wajah langsung diproses menggunakan TDLDA. Hasil akurasi pada model TDLDA ini dapat dilihat pada Tabel 1. Pada model pengenalan wajah dengan T-shape pada TDLDA ini dilakukan dengan mengambil piksel-piksel secara otomatis pada area wajah yang penting yaitu mata, hidung dan mulut sehingga membentuk seperti huruf $\mathrm{T}$ (T-shape) dapat dilihat pada Gambar 2. Hasil akurasi pengenalan wajah pada model $T$-shape otomatis pada TDLDA ini dapat dilihat pada Tabel 2, sedangkan hasil akurasi pengenalan wajah pada model T-shape interaktif pada TDLDA ini dapat dilihat pada Tabel 3.

Tabel 1. Hasil Eksperimen Citra Wajah dengan TDLDA

\begin{tabular}{ccccc}
\hline Jumlah data training & Precission & Recall & F-Measure & Waktu Komputasi (s) \\
\hline $\mathbf{5}$ & 0,93 & 1,00 & 0,97 & 28,87 \\
\hline $\mathbf{6}$ & 0,96 & 1,00 & 0,98 & 31,96 \\
\hline $\mathbf{7}$ & 0,98 & 1,00 & 0,99 & 36,16 \\
\hline
\end{tabular}

Tabel 2. Hasil Pengenalan Citra Wajah dengan T-shape Otomatis pada TDLDA

\begin{tabular}{ccccc}
\hline Jumlah data training & Precission & Recall & F-Measure & Waktu Komputasi (s) \\
\hline 5 & 0,79 & 1,00 & 0,88 & 25,66 \\
\hline 6 & 0,86 & 1,00 & 0,92 & 29,68 \\
\hline 7 & 0,91 & 1,00 & 0,95 & 32,93 \\
\hline
\end{tabular}

Tabel 3. Hasil Pengenalan Citra Wajah dengan T-shape Interaktif pada TDLDA

\begin{tabular}{ccccc}
\hline Jumlah data training & Precission & Recall & F-Measure & Waktu Komputasi (s) \\
\hline 5 & 0,91 & 1,00 & 0,95 & 22,67 \\
\hline 6 & 0,95 & 1,00 & 0,97 & 24,70 \\
\hline 7 & 0,96 & 1,00 & 0,98 & 28,76 \\
\hline
\end{tabular}

Hasil akurasi tingkat keberhasilan dilakukan dengan mambandingkan metode yang diusulkan pengenalan wajah dengan implementasi $T$-shape interaktif pada TDLDA dengan dua model metode pengenalan wajah yaitu TDLDA dan implementasi T-shape otomatis pada TDLDA. Metode yang diusulkan memiliki waktu training yang paling rendah dengan 22,67 detik jika dibandingkan dengan metode TDLDA tanpa T-shape dan T-shape secara otomatis. Hal ini dikarenakan pada TDLDA dengan $T$-shape interaktif, tidak semua piksel diolah untuk menjadikan fitur citra input-an. Gambar 7 menunjukkan metode implementasi $T$-shape dengan otomatis memiliki waktu lebih lama daripada $T$-shape secara interaktif. Karena dengan $T$-shape otomatis terlebih dahulu melalui tahap pengenalan objek pada mata dan mulut dengan menggunaan Haar like-feature, hal ini yang menambahkan waktu training-nya. Akan tetapi, 
implementasi $T$-shape otomatis memiliki waktu yang lebih baik daripada TDLDA tanpa menggunakan mask pada citra.

Implementasi T-shape Mask secara interaktif pada TDLDA memiliki tingkat akurasi atau precission yang mendekati TDLDA tanpa penggunaan masking. Hal ini ditunjukkan dengan pada jumlah data training sebanyak enam hanya selisih tingat akurasi $1 \%$ yaitu $T$-shape dengan tingkat akurasi 95\% sedangkan TDLDA dengan akurasi 96\%. Hal ini cukup efektif mengingat tidak semua piksel pada citra digunakan pada T-shape Mask. Implementasi T-shape Mask dengan otomatis memiliki tingkat akurasi paling rendah jika dibandingkan dengan dua metode lainnya seperti yang digambarkan pada Gambar 8. Hal ini karena dengan penentuan shape secara otomatis terlebih dahulu mencari area mata dan mulut, sehingga ketika data citra wajah miring seperti Gambar 9, terlihat semakin sedikit area piksel yang diproses pada ekstrasi fitur dengan menggunakan TDLDA.

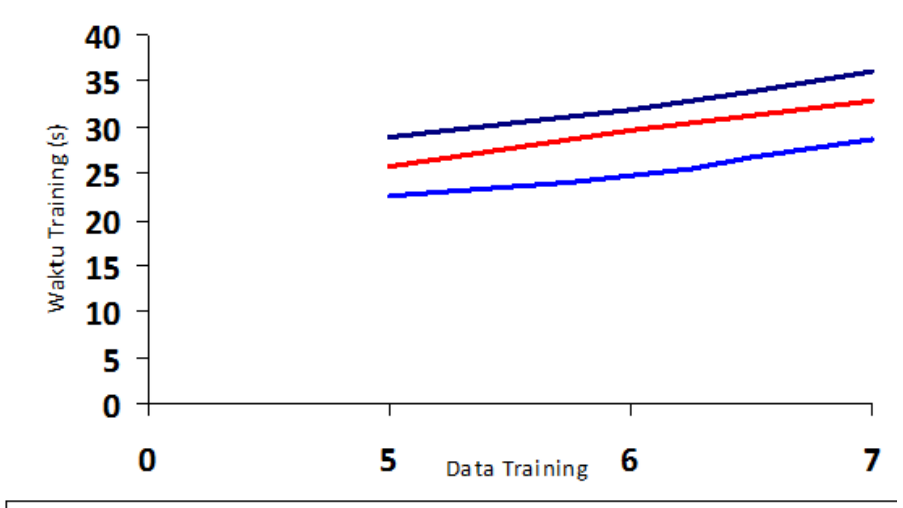

Gambar 7. Grafik Perbandingan Waktu Komputasi

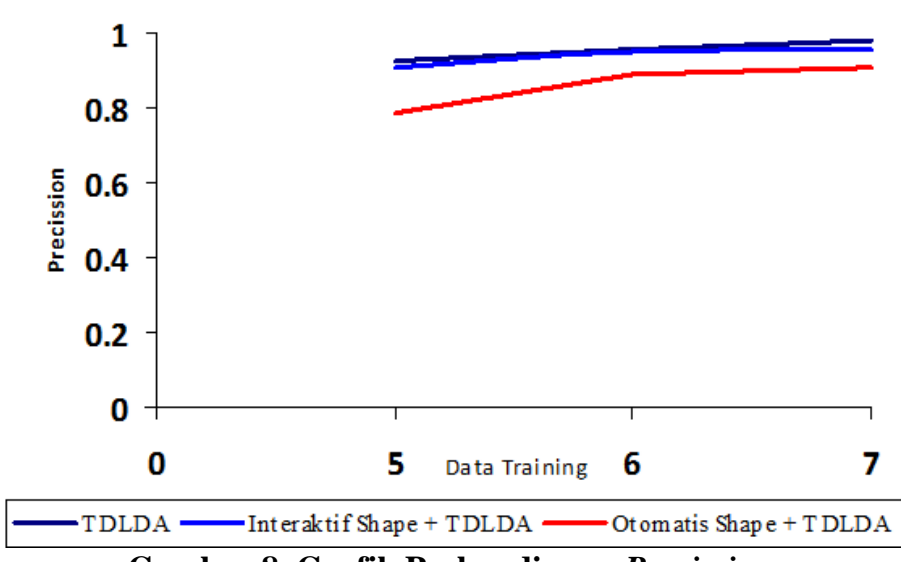

Gambar 8. Grafik Perbandingan Precission

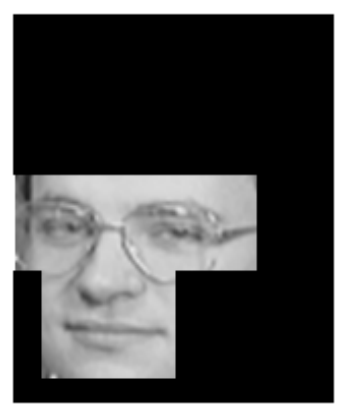

(a)

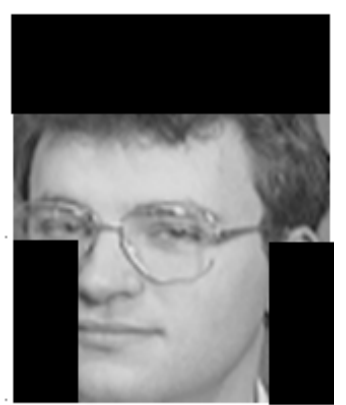

(b)

Gambar 9. Hasil T-shape Mask (a) Otomatis (b) Interaktif 
Dari hasil pembahasan diatas jelas bahwa dari aspek akurasi keberhasilan dan kompleksitas waktu pada pengenalan wajah dari tiga model yang dibandingkan implementasi $T$ shape Mask dengan menggunakan SVM memberikan hasil yang cukup efektif dalam pengenalan wajah dengan kompleksitas waktu yang lebih cepat serta hasil akurasi yang mendekati dengan metode TDLDA.

\section{Kesimpulan}

Pengenalan wajah menggunakan implementasi T-shape Mask secara interaktif pada Two Dimentional Direct Linier Analysis (TDLDA) dan Support Vector Machine (SVM) pada penelitian ini mampu menurunkan waktu komputasi saat training dari pada tidak menggunakan T-shape. Dari tiga kali ujicoba dengan jumlah data training yang berbeda-beda TDLDA dengan menggunakan $T$-shape interaktif lebih cepat $21,56 \%$ dibandingkan TDLDA tanpa menggunakan T-shape, dengan tingkat akurasi 91\%-96\% yang hampir mendekati tingkat akurasi tanpa menggunakan mask pada wajah. Penurunan kompleksitas perhitungan pada saat training ini dikarenakan dengan implementasi $T$-shape interaktif tidak semua piksel pada citra wajah digunakan, melainkan hanya piksel yang terdapat pada area $T$-shape saja yang digunakan.

\section{Saran}

Implementasi Penggunaan T-shape dan metode TDLDA pada pengenalan wajah diharapkan dapat dikembangkan untuk pengenalan wajah secara real time yang membutuhkan tingkat waktu perhitungan yang cepat.

\section{Referensi}

Belhumeur, P. N., \& Hespanha, J. P., \& Kriegman, D. J. 1997. Eigenfaces vs Fisherface: Recognition Using Class Specific Linear Projection. IEEE Transaction On Pattern Analysis And Machine Intelligence, 19, 711-720.

Burges, C. J. C. 1998. A Toturial on Support Vector Machines for Pattern Recognition. Data Mining and Knowledge Discovery, 2(2), 955-974.

Chung, B. W., Park, K. Y., \& Hwang, S. Y. 2013. A Fast and Efficient Haar-Like Feature Selection Algorithm For Object Detection. The Journal of Korean Institute of Communications and Information Sciences, 38(6), 486-491.

Damayanti, F., \& Arifin, A. Z. 2010. Pengenalan Citra Wajah Menggunakan Metode TwoDimensional Linear Discriminant Analysis dan Support Vector Machine. Jurnal Ilmiah Kursor, 5(3), 147-156.

Gao, Q., \& Zhang, L., \& Zhang, D. 2008. Face Recognition Using FLDA with Single Training Image Per Person. ScienceDirect, 205(2), 726-734.

Gu, X., \& Liu, C., \& Wang, S., \& Zhao, C. 2015. Feature Extraction Using Adaptive Slow Feature Discriminant Analysis. ScienceDirect, 154, 139-148.

Hsu, C. W. 2002. A Comparison of Methods for Multi-class Support Vector Machines. IEEE Transactions on Neural network, 13(2), 415-425.

Koc, M. \& Barkana, A. 2014. Discriminative Common Vector Approach Based Feature Selection In Face Recognition. ScienceDirect, 40(8), 37-50.

Kong, H., \& Wang, L., \& Teoh, E. K., \& Li, X., \& Wang, J. G., \& Venkateswarlu, R. 2005. Generalized 2D Principal Component Analysis For Face Image Representation and Recognition. ScienceDirect, 18(5), 585-594.

Lenc, L., \& Kral, P. 2015. Automatic Face Recognition System Based On The Sift Features. ScienceDirect.

Li, M., \& Yuan, B. 2005. 2D-LDA: A Statistical Linear Discriminant Analysis For Image Matrix. ScienceDirect, 26(5), 527-532.

Ma, C., \& Jung, J., \& Kim, S., \& Ko, S. 2015. Random Projection-Based Partial Feature Extraction For Robust Face Recognition. ScienceDirect, 149, 1232-1244.

Sinha, P., \& Balas, B. 2006. Face Recognition By Humans: Nineteen Results All Computer Vision Researchers Should Know About. Proc of the IEEE, 94(11), 1948-1962. 
Zhao, Y., \& Liu, Y., \& Zhong, S., \& Hua, K. A. 2015. Face Recognition From A Single Registered Image For Conference Socializing. ScienceDirect, 42, 973-979.

Zheng, W. S. 2008. 1D-LDA vs 2D-LDA: When is Vector-Based Linear Discriminant Analysis Better Than Matrix-Base. ScienceDirect, 2156-2172.

Zhi, R., \& Qiuqi, R. 2008. Two-dimensional Direct And Weighted Linear Discriminant Analysis For Face Recognition. ScienceDirect, 71, 3607-3611. 